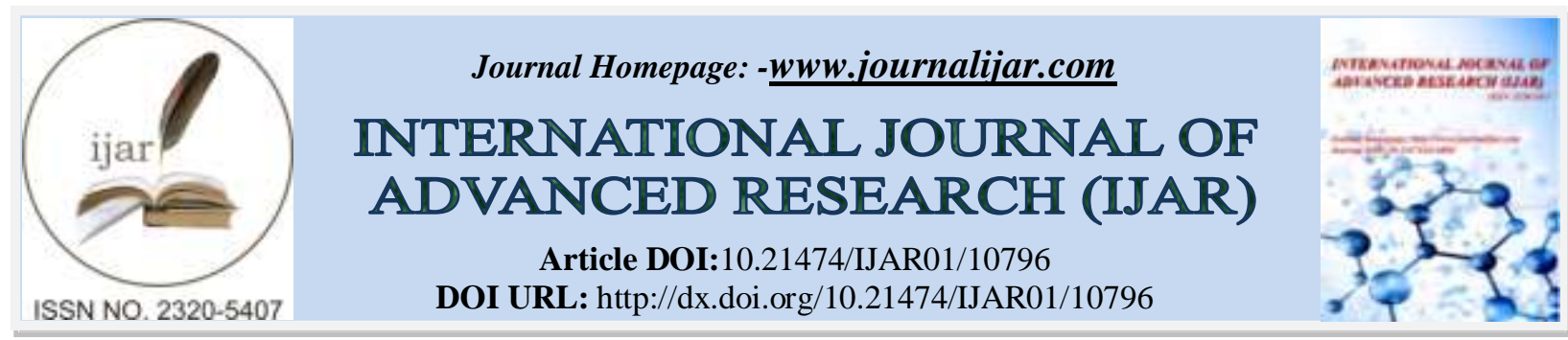

RESEARCH ARTICLE

\title{
POWER INSTABILITY AND THE PROFITABILITY OF SMALL AND MEDIUM ENTERPRISES (SMES) IN NIGERIA: A STUDY OF INDUSTRIAL SMES IN TRANS-AMADI PORTHARCOURT
}

\section{Eze Ikechukwu Robert ${ }^{1}$ and Eke Chinonso Karen ${ }^{2}$}

1. Department of Management Technology, School of Management Technology, Federal University of Technology, P.M.B 1526, Owerri, Imo State, Nigeria.

2. Department of Financial Management Technology, School of Management Technology, Federal University of Technology, P.M.B 1526, Owerri, Imo State, Nigeria.

\section{Manuscript Info}

Manuscript History

Received: 10 February 2020

Final Accepted: 12 March 2020

Published: April 2020

Key words:-

Power Instability, Electricity Shortage,

Sme, Profitability, Nigeria

\begin{abstract}
Nigeria, like most African countries, lack most basic infrastructure like electricity, water and accessible roads etc. The Nigerian government has employed different policies to improve this situation however the problem of electricity is yet to show any significant improvement; power generation has remained relatively same for the past 16 years, unreliable and unstable. This power instability's effect on businesses have been a major cause for concern to the Nigerian populace. The 2016 global oil crisis renewed the Nigerian government's quest to diversify the oil-dependent economy. The manufacturing sector which, among other things, is viewed as a medium to speed up diversification is highly electricity-dependent which has led to renewed interests on the effects of power shortages on manufacturing companies. This research assesses the effect of power instability on the profitabilityof industrial SMEs in Trans-amadi industrial area of Portharcourt, Nigeria. Out of the 150 companies sampled, the 112 that had audited records were studiedover a 4-year period (2015-2018) and using Eviews 10 to test the multivariate regression models, this study found that the natural $\log$ of cost of alternative power does not significantly affect operating profit and that power supply ratio does not have significant effect on the net profit of the SMEs within the study period.
\end{abstract}

Copy Right, IJAR, 2020,. All rights reserved.

\section{Introduction:-}

With the 2016 drop in global oil price that dragged the oil-dependent Nigerian economy into its worst recession in 25 years, the need for diversification has never been more evident (Bamidele, Isuma, \& Krik, 2016; Ishiekwene, 2016). It became even clearer at the end of 2015, when the manufacturing sector contributed about $\$ 2$ billion (two billion naira) more towards GDP than the oil and gas industry did (The Punch, 2016). The Nigerian government has, subsequently, taken up diversifying the economy, looking towards agriculture, steel mining, telecommunications, etc. (Ayodele et al. 2013; The Bankers' Committee 2016).

Small and medium-sized enterprises (SMEs) have been proven to be catalyst to economic development in countries all around the world (Ntiamoah, Opoku, Abrokwah, Baah-Frimpong, \& Agyei-Sakyi, 2014; Søilen \& Onuorah, 2009); they contribute significantly towards aspects of the economy like employment, wealth distribution, support 
services to large companies etc. According to Olayemi (2012), the manufacturing sector acts as a medium that helps speed up diversification and structural transformation of an economy. It helps the nation to fully utilize her resources so as to be self-sufficient and rely less on imports of finished goods or raw material for her economic development or sustenance. One of the main inputs in the manufacturing sector is the electricity which is useful in powering the machines needed for the various production processes. The manufacturing sector, therefore, needs adequate supply of electricity so as to function optimally (Ogechukwu, 2011; Okafor, Ugwuegbe, \& Ezeaku, 2016; Okufolami, 2003; Yusuf \& Dansu, 2013). A lack of which has been noted as one of the major setbacks to economic growth (Frederick \& Selase, 2014; Nwosa \& Oseni, 2012) with its effects spread across every aspect of the national development in developing countries. In Nigeria, despite the abundance of energy resources like oil, coal, solar, natural gas, wind and hydro resources etc. (Ezugwu, 2015; Iwayemi, 2008; Oyedepo, 2012), the shortage of electricity has become so common that the market for alternative power sources have seen continual boom. According toAbraham, Apochi, \& Ijuo, 2015; Ekpo (2009), Nigerian companies have recorded so many electricity blackouts that they rely on selfgenerating electricity options like generators, solar panels etc. despite the resultant impact on the cost of production. In an interview with Sky News in January 2016, Mr. Cole, the managing director of one of the major manufacturing industries in Nigeria, disclosed that their major constraint was electricity. According to him, because of the increased pump price (induced by the high cost of importing refined crude oil), they are unable to sustain the alternative source of power they use in place of the unreliable and epileptic public power supply. The narrations above go to identify two aspects of the problem; firstly, the most common alternative power sources (generators) are not also $100 \%$ reliable, scarcity of petroleum products (which is also common) can greatly affect it. Secondly, large companies are affected by the unreliable electricity supply despite their large economies of scale, which raises the question of how SMEs are affected by it. According to Lee \& Anas (1992) and Steinbuks \& Foster (2010), smaller firms are more affected by the electricity shortage because in addition to their inability to absorb the increased costs while maintaining competitive prices, about $20 \%$ to $25 \%$ of their initial capital investment is spent on providing themselves alternative power sources.

This study will assess how power instability in Nigeria affects the profitability of SMEs using a random sample of energy-dependent SMEs in Trans-Amadi industrial Layout of Portharcourt, Nigeria.

\section{Problem statement:}

The power situation in Nigeria has been a cause for concern for businesses, investors, government and citizens at large. Over the years, just like in many other developing countries, there has been significant study regarding power instability and fluctuations, many authors maintain that it remains one of the main catalysts delaying the growth of companies and economic development as a whole (Ado \& Josiah, 2015; Vita \& Kyaw, 2008).

Many companies (big and small) have been unable to automate some of their processes because of power instability and the high cost of alternative power among other things. The very high cost of running facilities such as the airport can be hugely attributed to power instability as some airports shut down some of its escalators and lifts to cut costs.

\section{Aims and Objectives:- course of this study, this aim is broken down into the following objectives; \\ 1. To assess the effect of power instability on operating profit of SMEs. \\ 2. To assess the effect of power instability on Net profit of the SMEs. \\ 3. To examine the effect of the cost of alternative power sources on profitability.}

From the above, the main aim of this study is to assess the effect of power instability on the profitability of the SMEs in Trans-Amadi Industrial Layout of Portharcourt, Nigeria, using a sample of 150 industrial SMEs. For the

Although the government have tried many different options (including but not limited to privatisation) in a bid to fight power instability, the lack of evident improvement has made the populace sceptical towards the government's ability to achieve constant power. Most big companies have secured big electricity generators as supplement to the unreliable public power so as to significantly reduce delay and idle time, with hope that their large economies of scale would absorb the increases in their operational cost. SMEs, on the other hand, are compelled to use alternative sources of power so as to remain a going concern this affects them in many different ways.

\section{Significance of study:}

The study will be of high significance to manufacturing companies (large, medium and small), consumers, government and scholars. 
1. For manufacturing companies, it will show the effects of thepower situation on their profit.

2. For consumers: It will show the possible reasons for fluctuations the landing cost of products.

3. For government: It will re-emphasize the need for infrastructural improvements in the power sector.

4. For scholars: It will serve as the source of literature for further research.

\section{Literature Review:-}

\section{History of electricity in nigeria:}

Electricity in Nigeria dates back to the Pre-Colonial era in the late 1800's when two small generating sets were installed to serve the then Colony of Lagos. The demand for electricity at the time was less than its $60 \mathrm{~kW}$ capacity (Niger Power Review, 1985). The Electricity Corporation of Nigeria (ECN) was established in 1951 by an act of parliament and by 1962, the Niger Dams Authority (NDA) was established to develop Hydro Electric power, however, the ECN and NDA were merged in 1972 to form the National Electric Power Authority (NEPA) although they maintained their functions. Due to the political climate in the country, for over 20 years prior to 1999, the power sector saw neither new substantial investment nor maintenance of existing infrastructures. By 2001, the demand for electricity was at about an average of 6,000MW while the installed capacity of 5,600MW had reduced to an average of $1,750 \mathrm{MW}$ with only 19 out of the 79 installed generating units operational (Folorunso \& Olowu, 2014; Sambo, 2005). In 2005, NEPA was reformed and renamed Power Holding Company of Nigeria (PHCN), as PHCN they were not solely responsible for the generation, transmission and distribution of electricity, rather, private companies were given opportunities to participate (Okoro \& Chikuni, 2007). This reform and deregulation made the power sector to comprise 11 distribution companies, 6 generating companies and one transmission company, of which only the transmission company was to be under the federal government. The reform and deregulation that led to this establishment of PHCN was to improve the power sector and cater for the inefficiencies of NEPA. By August 2005, electricity generation at its peak hit 3774 MW out of the $4000 \mathrm{MW}$ installed capacity which was largely attributed to the involvement of the private companies. However, from then to 2010, there was no significant difference between the production and capacity and that of 2005 despite the population growth (Folorunso \& Olowu, 2014). In 2013, the Nigerian government joined most developed nations to adopt the market-oriented system by privatising the power sector, hoping that the competition-led efficiency will help improve the power and subsequently, economic situation of the country, all to no avail (Nwogu et al., 2017).

As recent as January, 2017, the Transmission Company of Nigeria (TCN) reported that due to low water levels in the hydro power stations, the nation's power generation capacity has fallen from 3,959 MW to 2,662 MW (Premium Times, 2017) for 180 million people, which is significantly lower than Scotland with their approximately 17,000 MW installed capacity for a population of approximately 5.5 million people and about as much as is used by just Edinburgh (Annut et al., 2014; The Economist, 2016).

\section{Empirical evidence:}

In recent years, the question of how the shortage of power supply affects businesses (in terms of their profitability, efficiency, competitiveness, productivity etc.) has been a source of debate for authors and researchers around the world (e.g. Nwosa \& Oseni 2012; Cissokho \& Seck 2013; Rud \& Pablo 2012). Most of these researchers focus their research on manufacturing/ industrial firms because of their operations' dependence on electricity. Their findings differ; some find significant relationship between power instability and different aspects of the business like; profitability, productivity, competitiveness, efficiency etc., while others find insignificant relationships, some find negative relationships while others find positive. Since it was only recently that researchers commenced their focus on the study of the effect of power instability on SMEs, there are very few research works focused on Africa as a whole and even fewer on Nigeria. Because of this, the empirical evidence would not be restricted to the effect of power instability on profitability in Nigeria; rather, it would include the effects of power instability on the aspects of the manufacturing businesses in Nigeria, Africa and all other parts of the world.

One of the earliest studies on the electricity shortages in Nigeria, Ukpong (1973), studied the cost of power outages to manufacturing and industrial companies in Nigeria. Using the production function approach, he evaluated the power outage cost on the selected firms from 1965 to 1966 . He found that the unsupplied electricity has a significant negative effect on the productivity in the manufacturing and industrial companies in Nigeria.

Cissokho \& Seck (2013) studied the effect of electricity outages on the productivity of SMEs in Senegal using a survey of 528 businesses. They used a non-parametric approach based on Data Envelopment Analysis (DEA) in creating an efficient frontier while regression analysis was used in the measure of efficiency (technical and 
allocative). They found that power outages, frequency, duration and severity have significant negative effect on scale efficiency however; it had significant positive effect on cost and technical efficiencies.

Frederick \& Selase (2014) studied 70 systematically-sampled Ghanaian manufacturing SMEs to assess the effect of power fluctuations on their profitability and competitiveness. They used interviewer-administered structured questionnaires for data collection and SPSS Statistical package for data analysis and grouping. They found that power shortage has a negative significant effect on profitability and also reduces competitiveness.

Scott et al. (2014), in their report to the Department for International Development (DFID) on how electricity insecurity affects businesses in low and middle income countries, state, among other things, that, although, electricity instability has a negative impact on SMEs productivity, the impacts are usually statistically insignificant and can sometimes be negative. They studied manufacturing SMEs in 6 different countries (which includes Nigeria) using data from World Bank Enterprise survey and qualitative information from informants through semi-structured interviews, these data were analysed using regression analysis. They found that in four (which includes Nigeria) out of the six countries, electricity instability negatively affects the total factor productivity and labour productivity of the manufacturing SMEs.

Ado \& Josiah (2015) studied the impact of the deficient electricity supply on the operations of SMEs in North East Nigeria. They took a survey of the SMEs in the 6 North East states (Adamawa, Bauchi, Borno, Taraba, Yobe and Gombe) of Nigeria and used stratified random sampling techniques to select 468 SMEs. From this 468 sample, 312 structured questionnaires were distributed and 245 were retrieved, out of which only 241 were satisfactorily filled. Using Bivariate regression analysis, they analysed the impact of power shortage on the SMEs and found that the shortages have severe consequences for the SMEs because of their economies of scale.

Fisher-Vanden et al. (2014), in their study on how Chinese industrial firms maintain productivity in spite of power shortages, used data from a panel of 23,000 industrial companies. They found that the power shortages significantly affected productivity which made most of the energy-intensive companies that could afford it, to make a shift from "make" to "buy" for some of the intermediate production inputs while others sought alternative power sources; thus increasing the unit cost of production by as high as 8\%, however, during the study period (1999 to 2004), China experienced severe power shortages and that was the only way to remain a going concern.

Nyanzu \& Adarkwah (2016), in their research for the effect of power supply on SME performance in Ghana, used 710 firms from World Bank 2013 Enterprise survey to compare the SMEs in two industrial areas of Ghana, Tema and Northern Ghana. For pattern analysis, they employed the chi-square and t-test then used Ordinary Least Square (OLS) regression to regress performance variable on electricity supply variables and control variables. They found that power outages have a significant negative effect on the SMEs performance which is more sever in Northern Ghana than in Tema.

Mensah (2016), in the study of the level of impact of power outages in companies using panel data from 15 countries in Sub-Saharan Africa (SSA) (which includes Nigeria), found that that in general electricity shortages have significant negative effects on the revenue and productivity of the firms. From the regression results, the study found that among the 15 SSA countries sampled (Nigeria, Guinea, Central African Republic, Republic of Congo, The Gambia, Chad, Niger, Burundi, Sierra Leone, Democratic Republic of Congo, Burkina Faso, Cameroon, Tanzania, Ghana and Togo), the firms in Nigeria experience the most power shortages and are most affected while the South African firms are least affected.

From the above, we can see that none of the studies is focused on industrial manufacturing SMEs, this research fills that gap. The study focuses mainly on SMEs in and around Trans-amadi industrial layout of Portharcourt Nigeria. This means that the SMEs sampled are sited around the same location and undergo the same power supply fluctuations and all other conditions. Therefore, the researchers expect that the supply of power and need for alternative sources of power will be relatively similar among them.

\section{Hypothesis Development:}

For the development of the study hypothesis, the authors consider two of the measures of profitability; net profit margin and gross profit margin (Adeniji, 2008). While for the unreliable power supply, the authors consider the power supplied, ratio of power supplied to power needed and the cost spent on alternative power sources. The 
choice of what power instability measure to match against each of the dependent variables was based on the authors' assessment of their relativity;

The cost of alternative source of power increases the operational cost (Ogechukwu, 2011), hence;

\section{Hypothesis 1:}

there is no significant relationship between cost of alternative power sources and operating profit in the sample industrial SMEs.

Power supply affects the overall profitability of SMEs (Frederick \& Selase, 2014) hence;

\section{Hypothesis 2:}

there is no significant relationship between the power supply ratio and Net Profit.

\section{Methodology:-}

Data andsample selection:

For this study, the researchers choose industrial SMEs over a 4-year period (2015-2018). According to the Central Bank of Nigeria (CBN) in their 2002 quarterly publication quoted in (Eze \& Okpala, 2015), SMEs are companies that have at least N3,000,000.00 (Three Million Naira only) in turnover. The SMEs were randomly sampled from documented and undocumented SMEs located within Trans-Amadi industrial area out of which 38 companies were excluded for insufficient and unaudited records. The final sample contained 112 companies. In Table 1, the companies are grouped according to their various industries, the largest group being 67 oil servicing companies while the smallest is 11 food processing companies.

Table 1:- Distribution of the Sample Companies by Industry.

\begin{tabular}{|l|l|l|}
\hline INDUSTRY & NO. OF SMEs & $\%$ of Total SMEs \\
\hline Petrol stations & 18 & 16.1 \\
\hline Food processing & 11 & 9.8 \\
\hline Oil servicing & 67 & 59.8 \\
\hline Metal work & 16 & 14.3 \\
\hline Total & 112 & 100 \\
\hline
\end{tabular}

\section{Data:}

Data on audit, machine breakdowns revenue growth, SME's age, leverage, Tax, performance (profit or loss) etc. are hand-collected from the sample SMEs' annual reports. As regards data analysis, the researchers used Excel 2010 and Eviews 10.

\section{Measurement of Variables: \\ Measurement of Dependent Variables:}

The study adopts operational and net profit margin as measures of profitability against all the other measures. The researchers chose operating and net profit margin as the two measures of profitability for this study because; for operating profit, the SMEs are industrial SMEs and their major power needs are in their operations; unlike gross profit, operating profit does not only take into account the cost of producing the product rather, it considers total expenses incurred in the production process including wages, factory rent, factory power etc. while the net profit considers other expenses and shows resulting effect on bottom line.

The study runs 2 groups of tests; one for each measure of profitability against each power instability measures (Natural log of Power supply, power supply ratio), in order to assess the significant association between them.

\section{Measurement of Independent Variable:}

As mentioned in $\mathbf{1 . 4}$ above, the power supply ratio (the supposed cost of power (Kilowatts (KWs) required * Cost per $\mathrm{KW}$ ) to total spent by sample companies) is adopted as evidence of the level of power instability in addition to the natural $\log$ of actual power supply and natural $\log$ of the cost of alternative power sources as measures of the effect of power instability.

To measure the relationship between power instability and profitability, the researchers designed two multivariate models with some control factors which are considered to have an effect on the measurements of profitability. 


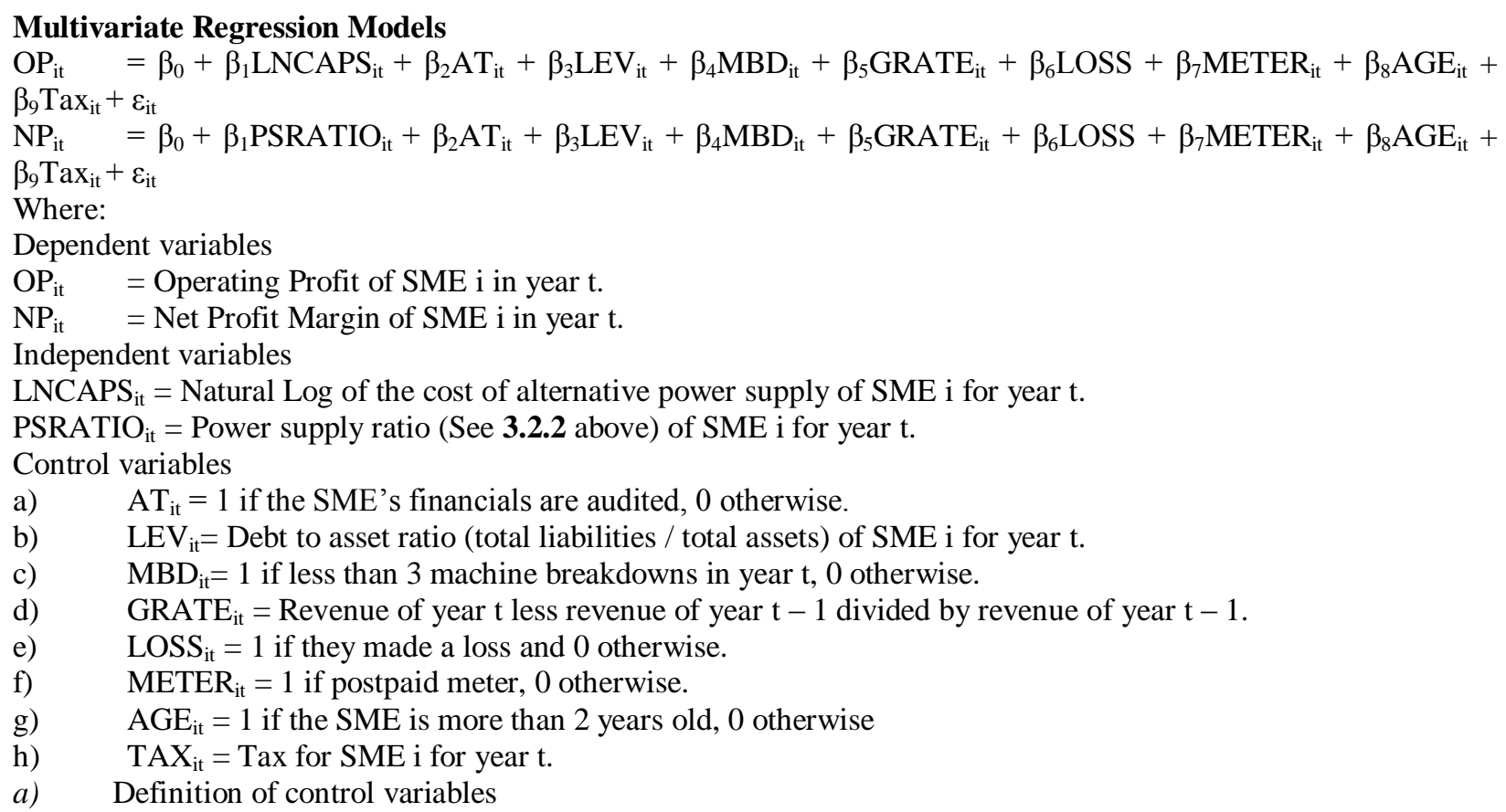

Audited financial records (AT):

Although the sample SMEs are privately owned and are not listed on any stock exchange, there is still need for audited financial records as it gives a second unbiased opinion thereby, increasing the quality and credibility of the financial records prepared by the management (Ojo, 2006). Arshad et al. (2011) found a positive relationship between audit (internal \& external) and both firm profitability. In this study therefore, AT is fit as a control variable and is represented using dummy values.

Leverage (LEV):

For the cause of this study, leverage is defined as total liabilities divided by total assets in the year. Larry et al. (1995) in their study of Ghanaian companies found a positive relationship between leverage and profitability which they attributed to the lower cost of debt in Ghana at the time; it was cheaper to borrow funds than to use internally generated funds. However, Wald (1999); Eunju \& SooCheong (2005); Javed et al. (2015) indicate that financial leverage is negatively related to profitability arguing that higher levered firms tend to have lower profitability and vice versa usually because of the continual and high amount of interests needed to sustain their debt contracts. So, high leverage will reduce the profitability of the SMEs that are highly levered. Leverage is, therefore, considered a control variable in this study.

Machine Breakdown (MBD):

Machine breakdown is one of those factors that directly affect the production process especially as it relates to yield (Konopka \& Trybula, 1996; Sheu \& Lin, 2006). Frequent machine breakdowns could result in low standards of production and increase the cost of machine maintenance, inability to deliver order within agreed time and subsequently, loss of customers. To achieve optimum production, machines undergo preventive maintenance so as to be readily available at needed times and eliminate unwanted wastage due to breakdowns. More than 3 machine breakdowns in a year show a significant lack of proper maintenance which, according to Subramanian et al. (2009), affects production and profitability at large. Since SMEs that have more machine breakdowns are likely to have low profitability, machine breakdown is considered a control variable for the cause of the study.

\section{Revenue Growth Rate (GRATE):}

Penrose (1995) and Goddard et al (2004) found a negative relationship between growth and profitability; according to them, firm growth does not influence future profitability rather growth is achieved because the "economy of growth" allows it. They added that rapid growth breeds high operating cost, therefore, the companies with slower growth tend to be more profitable. While Coad \& Rao (2008); Bottazzi et al. (2011), found no significant relationship between them. Lee (2014), Jang \& Park (2011), Coad (2007) and Yoo \& Kim (2015), on the other hand, indicate that in a stable economic environment, there is a significant positive relationship between revenue growth 
and profitability; high revenue growth from the previous period increases profitability in the current period. They emphasized on the importance of maintaining a balance between growth and profitability. Revenue growth rate is included to control for the effect (if any) it has on profitability.

\section{Loss (LOSS):}

When a business is running at a loss, it means that money spent is more than money received from the business operations. It is often seen in some new businesses in periods of growth. Companies that are at a loss making financial position maybe compelled to reduce operational output due to the downturn in their business cycle which affects the possibility of a future profit position (Broere, 2013).

\section{Type of Electricity Meter (METER):}

The type of electricity meter is considered because of the difference in billing method; those that use prepaid meters pay for the exact amount of power they use while those on post-paid are given estimated bills. Estimated bills make it difficult to assess the actual public power supplied within a given time. For post-paid meters, because the estimation is rarely exact, the electricity expense maybe either lower than it is supposed to be or higher, which would result in either increased or decreased profit.

\section{SME's Age (AGE):}

Coad et al. (2013) Hui et al. (2013) and Ilaboya et al. (2016) indicate a positive relationship between firm age and profitability which suggests that the older the firm, the higher its profitability and performance. Akben-Selcuk (2016), on the other hand, found a negative relationship between firm age and profitability. The likelihood of a relationship between the firm age and profitability makes it necessary to control for it.

\section{Taxation (TAX):}

Graham et al. (2013), Beigi et al. (2013) and Woo et al. (2012) found a negative significant relationship between tax and profitability which means that as taxation increases, profitability reduces and vice versa. Changes in tax rates by government will directly affect the profitability of the SMEs.

\section{Analysis and interpretation of data:}

\section{Regression results:}

The researchers found that contrary to the regression modeling assumptions, the error term $(\varepsilon)$ of the three regression models had a pattern, a condition referred to as heteroscedasticity which questions the credibility of the t-test, $\mathrm{f}$ test and $\mathrm{R}^{2}$ results in an OLS regression (Gujarati \& Porter, 2009). The authors include White's Heteroscedasticityconsistent standard errors and covariance test in the tests of the regression models so as to account for heteroscedasticity.

\section{Model 1:}

$\mathrm{OP}_{\text {it }}=\beta_{0}+\beta_{1} \mathrm{LNCAPS}_{\text {it }}+\beta_{2} \mathrm{AT}_{\text {it }}+\beta_{3} \mathrm{LEV}_{\mathrm{it}}+\beta_{4} \mathrm{MBD}_{\mathrm{it}}+\beta_{5} \mathrm{GRATE}_{\text {it }}+\beta_{6} \mathrm{LOSS}+\beta_{7} \mathrm{METER}_{\mathrm{it}}+\beta_{8} \mathrm{STAFF}_{\text {it }}+\beta_{9}$ Tax $_{\text {it }}$

\section{Equation 1 Regression Result:}

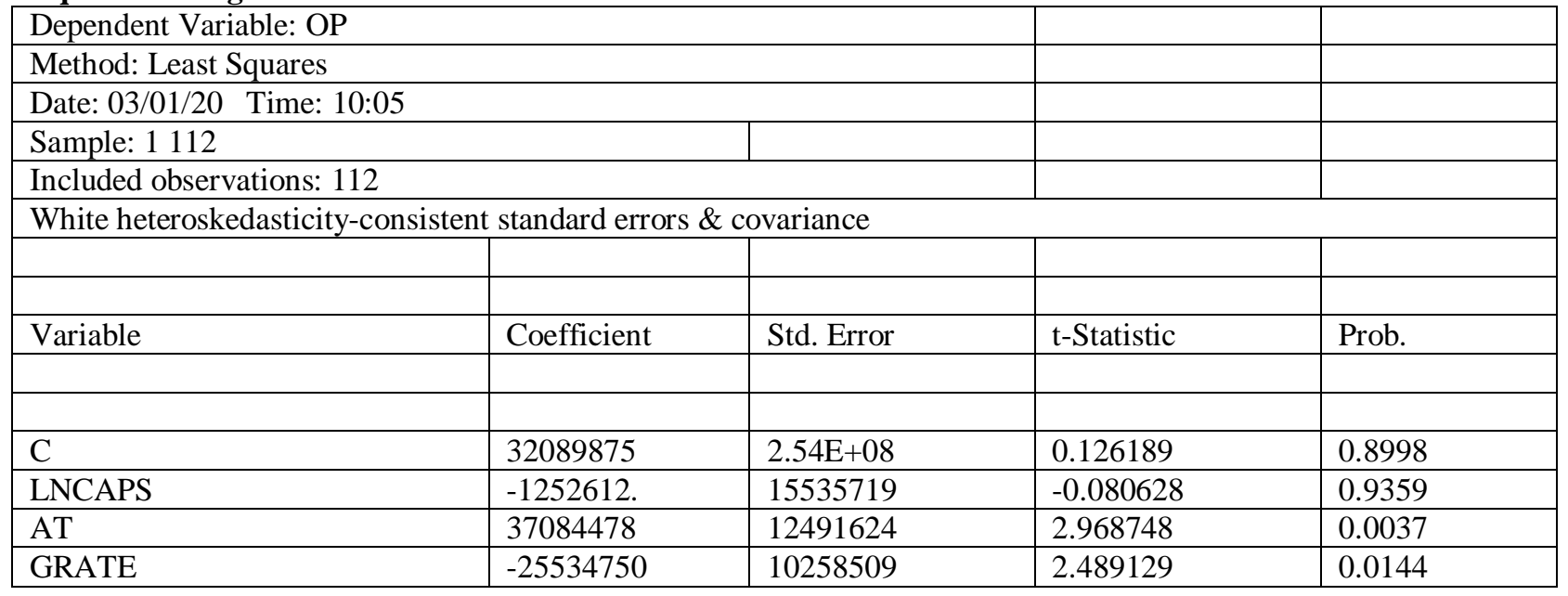




\begin{tabular}{|l|l|l|l|l|}
\hline LEV & -1968410. & 895250.6 & -2.198726 & 0.0302 \\
\hline LOSS & 40014069 & 11753654 & -3.404394 & 0.0009 \\
\hline MBD & -1647432. & 15287845 & -0.107761 & 0.9144 \\
\hline METER & -3937981. & 13101088 & -0.300584 & 0.7643 \\
\hline AGE & 3166869. & 13393370 & 0.236451 & 0.8136 \\
\hline TAX & -9.130901 & 9.881330 & -0.924056 & 0.3576 \\
\hline & & & & \\
\hline & & & & \\
\hline R-squared & 0.133736 & Mean dependent var & 59041908 \\
\hline Adjusted R-squared & 0.057301 & S.D. dependent var & 67559853 \\
\hline S.E. of regression & 65595686 & Akaike info criterion & 38.92096 \\
\hline Sum squared resid & $4.39 \mathrm{E}+17$ & Schwarz criterion & 39.16369 \\
\hline Log likelihood & -2169.574 & Hannan-Quinn criter. & 39.01944 \\
\hline F-statistic & 1.749666 & Durbin-Watson stat & 1.803717 \\
\hline Prob(F-statistic) & 0.087273 & & \\
\hline & & & & \\
\hline & & & & \\
\hline
\end{tabular}

From the results above, in terms of the explanatory variable, since the p-values for the coefficient of LNCAPS is greater than 0.05 , the natural log of the cost of alternative power sources (LNCAPS) has a statistically insignificant negative effect on the measure of profitability, operating profit (OP). This result confirms hypothesis one that the cost of alternative power sources does not significantly affect operating profit. It is consistent with the findings by Scott et al. (2014); power instability may affect SMEs profitability, productivity etc. but this effect is usually insignificant. This result could be translated to mean that there are other factors that have more significant effect on operating profit than power supply.

In terms of the control variables, at a $5 \%$ test of significance (p-value $<0.05$ );

1. The annual audit of the SMEs records (AT) shows a statistically significant positive relationship with the net profit. This is consistent with the research by Arshad et al. (2011) that companies with audited financials tend to aim for better performance because the possibility of manipulation of figures or any of such sharp practices may not be achievable.

2. The growth rate of revenue (GRATE) shows a statistically significant negative relationship with operating Profit (OP). This result is consistent with Penrose (1995) and Goddard et al. (2004) but inconsistent with Coad \& Rao (2008) and Bottazzi et al. (2011).

3. Leverage (LEV) shows a statistically significant negative relationship with operating profit (OP). This agrees with the arguments by Wald (1999), Eunju \& SooCheong (2005) and Javed et al. (2015).

4. Loss (LOSS) shows a very strong statistically significant negative relationship with operating profit (OP); this means that the loss-making position of $78 \%$ of the sample SMEs (as shown in table 5) affected the operating profit. According to Sivarethinamohan (2010) loss making companies scale down their operations and embark on several measures to cut cost.

All the other variables had no statistically significant relationship with operating profit. Although the $\mathrm{R}^{2}$ figure shows that the model explains just about $13.37 \%$ of the variability in data, the F-Statistic indicates that a $10 \%$ significance level, the model is a good one and some of the variables in the model have a significant effect on the dependent variable OP.

Model 2:

$\mathrm{NP}_{\text {it }}=\beta_{0}+\beta_{1}$ PSRATIO $_{\text {it }}+\beta_{2} \mathrm{AT}_{\text {it }}+\beta_{3} \mathrm{LEV}_{\text {it }}+\beta_{4} \mathrm{MBD}_{\mathrm{it}}+\beta_{5} \mathrm{GRATE}_{\mathrm{it}}+\beta_{6} \mathrm{LOSS}+\beta_{7} \mathrm{METER}_{\mathrm{it}}+\beta_{8} \mathrm{STAFF}_{\mathrm{it}}+$ $\beta_{9} \operatorname{Tax}_{\text {it }}$

\section{Equation 2 Regression Result:}

\begin{tabular}{|l|l|l|l|}
\hline \multicolumn{2}{|l|}{ Dependent Variable: NP } & & \\
\hline Method: Least Squares & & \\
\hline Date: $03 / 01 / 20$ Time: $10: 06$ & & & \\
\hline Sample: 1112 & & \\
\hline
\end{tabular}




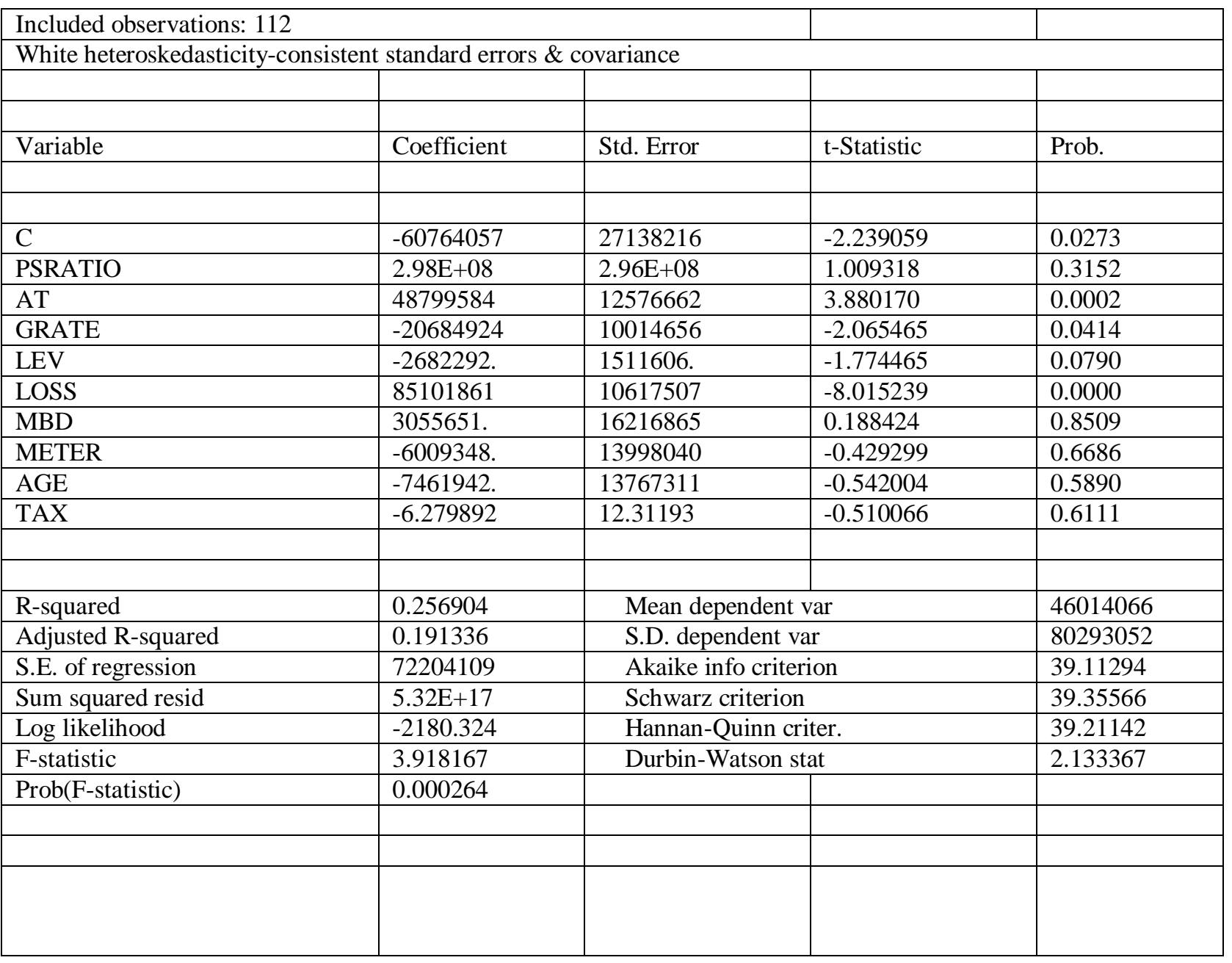

From the Model 2 results above shows that power supply ratio (PSRATIO) has no statistically significant effect on, the second measure of profitability employed in this study, net profit (NP) since the p-values for the coefficients of PSRATIO is greater than 0.05. This result confirms hypothesis two, that the PSRATIO of the SMEs as defined have no significant association with the net profit they declare; for the SMEs, the ratio of public power supply and the actual power supply needed for optimum production does not significantly affect their bottom line. This consistent with the expectations of this study; because the SMEs are manufacturing SMEs and their electricity needs are in their operations, if power instability does not significantly affect the operating profit, the likelihood of it affecting the net profit is very low. Just like in the result of Model 1 above, the operating profit result, in terms of the control variables, AT, GRATE and LOSS are have statistically significant effect on net profit at a 5\% test of significance (pvalue < 0.05 );

1. The annual audit of the SMEs records (AT) shows a statistically significant positive relationship with the net profit. This is consistent with the research by Arshad et al. (2011) that companies with audited financials tend to aim for better performance because the possibility of manipulation of figures or any of such sharp practices may not be achievable.

2. The growth rate of revenue (GRATE) shows a statistically significant negative relationship with Net Profit (NP). This result is consistent with Penrose (1995) and Goddard et al. (2004) but inconsistent with Coad \& Rao (2008) and Bottazzi et al. (2011).

3. Loss (LOSS) shows a very strong statistically significant positive relationship with net profit; this means that the loss-making position of $78 \%$ of the sample SMEs (as shown in table 5) affected the net profit. According to Sivarethinamohan (2010) loss making companies scale down their operations and embark on several measures to cut cost. 
All the other control variables had no statistically significant relationship with net profit. The $\mathrm{R}^{2}$ figure shows that the model explains just about $25.69 \%$ of the variability in data, however, the F-Statistic indicates that a $1 \%$ significance level, the model is a good one and some of the variables in the model have significant effect on the dependent variable NP.

\section{Conclusion and Recommendations:- Conclusion:-}

The results from this study show that the industrial SMEs in Trans-Amadi Portharcourt, Nigeria, suffer high power instability, the power supply saw continued reduction that has led to the continual growth in the market for alternative power sources; from the average of the power supply ratio shown under Table 3, the study shows that only about $6 \%$ of the electricity demand of the SMEs were met by public power supply. However, since all of them had back-up alternatives like generators, inverters, solar panels and etc., the increase in operational cost is expected to, at least, significantly affect operating profit, which is not the case; the increased cost significantly affected neither the operating profit nor the net profit. After further content analysis, the study found that there could be other reasons why the operating profit and net profit are not significantly affected; $78 \%$ of the SMEs in the sample recorded loss- making positions which led to reduced operations and, subsequently, low sales within the study period. This had more significant effect on the operating profit than operating expenses (including electricity), and by so doing, it resulted in the lack of effect on the SMEs bottom line (net profit). The effect of power instability on the profitability of the minority (22\%) that did not record loss (if any) cannot be accurately identified from the sample result. The effect of power instability is not restricted to the companies rather it spreads across the economy; the increased cost of production eventually leads to increased cost of items, which leads to increased cost of living, making more people poor in the economy.

Overall, the findings disagree with authors like Alam (2013), Adenikinju (2005) and Frederick \& Selase (2014) and several others who found that power instability has a significant effect on profitability. It, however, agrees with (Scott et al. (2014), Olayemi (2012) and Fisher-vanden et al. (2014) who found that power shortage and fluctuations has significant negative effect on productivity.

In conclusion, this study highlights the basic problem that contributes to the delay in economic development in Nigeria and most African countries through the problems of SMEs. This research also shows that stable and reliable electricity will improve the efficiency of the industrial and electricity-dependent businesses and reduce their operational costs, a reduction that can also contribute towards improving the profit declared by the businesses. The lack of constant and sufficient power production from the existing infrastructure has not only added to the delay in economic growth and development but has also made it difficult for countries like Nigeria to even discuss advancements towards green energy sources. This study will add to the existing literature on the areas the government should focus on so as to ensure that SMEs function optimally and attain their expected capacity (Okeke, Ezenwafor, \& Femiwole, 2013).

\section{Limitations Of The Research:}

There are several limitations to this study;

Firstly, the sample size; although studying 112 companies out of the 468 documented industrial SMEs in TransAmadi, Portharcourt, for a 4 year period is relatively easier, however, when compared to Adenikinju (2005) who studied 39,000 firms across 19 states of Nigeria, the sample is small. Because of financial constraints, the researchers would find it difficult to embark on a research with a sample size this large.

Secondly, the classification of power supply; power supply was computed based on the amount paid per month and the unit cost per kWh, however, over half of them sample SMEs used post-paid meters which means that there may be variations (they may have either under paid or over paid); prepaid meters may turn out different results.

Thirdly, the control variables in the regression model are limited to the researchers' capabilities, there could be other factors that could affect operating and net profit that were not included like firm size, sales, ownership structure, management, etc. 
Fourthly, the research method is quantitative. The use of both the quantitative and qualitative research methods (mixed research methods) is theorised better than just quantitative or just qualitative method because it is a combination of the advantages of the two methods (Creswell, 2007, 2009).

Lastly, based on the ownership structure of the SMEs and since none of them are listed on any stock market, there is a likelihood that the financial records are prepared on varied individual standards which may affect the research results.

\section{Recommendations:-}

The recommendations are mainly based on this research and the limitations listed above and are aimed at future researchers and government policy makers;

For future researchers, as mentioned above, the sample of this research could be stretched to include industrial SMEs from different states of the federation and not restricted to an industrial area. The study could include SMEs with pre-paid meters that are listed on the Nigerian Stock Exchange (NSE), by so doing, their financial records can be comparable. It may even be extended to include cross-listed SMEs that have at least two financial standards to uphold so as to see if the results remain the same. Scott et al. (2014) states that the results may be influenced by how power instability is measured, suggesting that for future research, the duration of outages should be used as a measure, therefore, the duration of the power outages can be tested based on the multivariate models in this research in future.

For government policy makers, the researchers recommend that the government invests money to improve the necessary infrastructure that would enable more power production and set a penalty for each individual power plant that does not meet the required production and distribution level. According to Price et al. (2002), such penalties will only be effective if they are compulsory.

\section{References:-}

1. Abraham, O., Apochi, M. P., \& Ijuo, A. S. E. (2015). Electricity Supply and the Manufacturing Productivity in Nigeria (1980-2012). IOSR Journal of Economics and Finance Ver. I, 6(6), 90-94. https://doi.org/10.9790/5933-06619094

2. Adeniji, A. A. (2008). An Insight into: Management Accounting (Fourth). Lagos: EL-TODA Ventures Limited.

3. Adenikinju, A. (2005). An Analysis of the Cost of Infrastructure Failure in a Developing Economy: The Case of Electricity Sector in Nigeria. (No. AERC Research Paper 148).

4. Ado, A., \& Josiah, M. M. (2015). Impact of Deficient Electricity Supply on the Operations of Small Scale Businesses in North East Nigeria. International Journal of Business and Economic Development, 3(1), 20-30.

5. Akben-Selcuk, E. (2016). Does Firm Age Affect Profitability? Evidence from Turkey. International Journal of Economic Sciences, 5(3), 1-9.

6. Alam, M. M. (2013). Coping with Blackouts : Power Outages and Firm Choices. Department of Economics, Yale University.

7. Annut, A., Williams, M., Michaels, C., Spry, W., Forster, J., Earp, M., ... Hemingway, J. (2014). ENERGY TRENDS. Department of Energy and Climate Change. Retrieved from https://www.gov.uk/government/uploads/system/uploads/attachment_data/file/357432/ET_Sep_14.PDF

8. Arshad, M. A., Satar, R. A., Hussain, M., \& Naseem, M. A. (2011). Effect of Audit on Profitability: A Study of Cement Listed Firms, Pakistan, 11(9).

9. Ayodele, O., Akongwale, S., \& Nnadozie, U. P. (2013). Economic Diversification in Nigeria: Any Role for Solid Mineral Development? Mediterranean Journal of Social Sciences, 4(No 6). https://doi.org/10.5901/mjss.2013.v4n6p691

10. Bamidele, O., Isuma, M., \& Krik, L. (2016). Nigeria In Worst Recession In 29 Years. Retrieved February 15, 2017, from http://independentnig.com/nigeria-in-worst-recession-in-29-years/

11. Beigi, M. R., Rafat, B., \& Mozafari, P. H. (2013). The analysis of the effect of tax on profitability indices in listed companies of Tehran Stock Exchange. European Online. Journal of Natural and Social Sciences, 2(3), 86.

12. Bottazzi, G., Coad, A., Jacoby, N., \& Secchi, A. (2011). Corporate growth and industrial dynamics: Evidence from French manufacturing. Applied Economics, 43(1), 103-116.

13. Broere, M. (2013). Decision-making in private equity firms: an empirical study of determinants and rules. . Springer Science \& Business Media. 
14. Cissokho, L., \& Seck, A. (2013). Electric Power Outages and the Productivity of Small and Medium Enterprises in Senegal. Investment Climate and Business Environment Research Fund, (November), 1-30. Retrieved from http://trustafrica.org/en/publications-trust/icbe-research-reports?download=354:electric-power-outages-and-theproductivity-of-small-and-medium-enterprises-in-senegal

15. Coad, A. (2007). Testing the principle of 'growth of the fitter': the relationship between profits and firm growth. Structural Change and Economic Dynamics, 18(3), 370-386.

16. Coad, A., Frankish, J., Roberts, R. ., \& Storey, D. J. (2013). Growth paths and survival chances: An application of Gambler's Ruin theory. Journal of Business Venturing, 28(5), 615-632.

17. Coad, A., \& Rao, R. (2008). Innovation and firm growth in high-tech sectors: A quantile regression approach. Research Policy, 37(4), 633-648.

18. Creswell, J. W. (2007). Understanding mixed methods research. Qualitative Inquiry and Research Design: Choosing Among Five Approaches, 11(2), 1-19. https://doi.org/10.1016/j.aenj.2008.02.005

19. Creswell, J. W. (2009). Research design: Qualitative, quantitative, and mixed methods approaches. Research Design Qualitative Quantitative and Mixed Methods Approaches, 3rd, 260. https://doi.org/10.1016/j.math.2010.09.003

20. Ekpo, U. N. (2009). Public Investment and Infrastructural Development: The Case of Electric Power Supply in Nigeria (1970-2004). University of Uyo, Uyo, Nigeria.

21. Eunju, Y., \& SooCheong, J. (2005). The Effect of Financial Leverage on Profitability and Risk of Restaurant Firms. Journal of Hospitality Financial Management, Vol. 13(Iss. 1), Article 24. Retrieved from http://scholarworks.umass.edu/jhfm/vol13/iss $1 / 24$

22. Eze, T. C., \& Okpala, C. S. (2015). QUANTITATIVE ANALSIS OF THE IMPACT OF SMALL AND MEDIUM SCALE ENTERPRISES ON THE GROWTH OF NIGERIAN ECONOMY: (1993-2011). International Journal of Development and Emerging Economics, 3(1), 26-38.

23. Ezugwu, C. N. (2015). Renewable Energy Resources in Nigeria : Sources, Problems and Prospects, 3(1), $68-$ 71. https://doi.org/10.7763/JOCET.2015.V3.171

24. Fisher-vanden, K., Mansur, E. T., \& Wang, Q. J. (2014). Electricity Shortages and Firm Productivity : Evidence from China' s Industrial Firms, 1-63.

25. Folorunso, O., \& Olowu, T. (2014). The Nigerian Power System Till Date : A Review ., 1(5), 20-33.

26. Frederick, D., \& Selase, A. E. (2014). The Effect of Electric Power Fluctuations on the Profitability and Competitiveness of SMEs: A Study of SMEs within the Accra Business District of Ghana, 6(3), 32-48. https://doi.org/10.7441/joc.2014.03.03

27. Goddard, J. A., Molyneux, P., \& Wilson, J. O. (2004). Dynamics of growth and profitability in banking. Journal of Money, Credit, and Banking, 36(6), 1069-1090.

28. Graham, J. R., Hanlon, M., Shevlin, T., \& Shroff, N. (2013). Incentives for tax planning and avoidance: Evidence from the field. The Accounting Review, 89(3), 991-1023.

29. Gujarati, D. N., \& Porter, D. C. (2009). Basic Econometrics (Mc-Graw Hi). Palgrave Macmillian.

30. Hui, H., Radzi, W. M., Jasimah, C. W., Jenatabadi, H. S., Abu Kasim, F., \& Radu, S. (2013). The impact of firm age and size on the relationship among organizational innovation, learning, and performance: A moderation analysis in Asian food manufacturing companies.

31. Ilaboya, O. J., Izevbekhai, M. O., \& Ohiokha, F. I. (2016). Tax Planning and Firm Value: A Review of Literature. Business and Management Research, 5(2), 81.

32. Ishiekwene, T. (2016, October 5). Worst Economic Crisis In 25 Years: What Nigeria Can Do To Get Out Of Recession? Sahara Reporters. Retrieved from http://saharareporters.com/2016/10/05/worst-economic-crisis-25years-what-nigeria-can-do-get-out-recession-tony-ishiekwene

33. Iwayemi, A. (2008). Nigeria's Dual Energy Problems: Policy Issues and Challenges. International Association for Energy Economics, (2), 17-21.

34. Jang, S. S., \& Park, K. (2011). Inter-relationship between firm growth and profitability. International Journal of Hospitality Management, 30(4), 1027-1035.

35. Javed, H. Z., Rao, H., Akram, B., \& Nazir, M. F. (2015). Effect of Financial Leverage on Performance of the Firms : Empirical Evidence from Pakistan. Journal of Economics and Business, 65(1), 87-95.

36. Konopka, J., \& Trybula, W. J. (1996). Overall equipment effectiveness (OEE) and cost measurement [semiconductor manufacturing]. In Proceedings of the IEEE/CPMT International Electronics Manufacturing Technology (IEMT) Symposium. Nineteenth IEEE/CPMT. https://doi.org/10.1109/IEMT

37. Larry, L., Ofek, E., \& Stulz, R. (1995). Leverage investment and firm growth. Journal of Financial Economics, 40(2), 3-29. 
38. Lee, K. S., \& Anas, A. (1992). Costs of deficient infrastructure: the case of Nigerian manufacturing. Urban Studies, (29), 1071-1092.

39. Lee, S. (2014). The relationship between growth and profit: evidence from firm-level panel data. Structural Change and Economic Dynamics, 28, 1-11.

40. Mensah, J. T. (2016). Bring Back our Light: Power Outages and Industrial Performance in Sub-Saharan Africa. Department of Economics,Swedish University of Agricultural Sciences, Uppsala-Sweden, 1-25.

41. Niger Power Review. (1985). Development of the Electricity Industry in Nigeria (1960-1985), 1-6.

42. Ntiamoah, E. B., Opoku, B., Abrokwah, E., Baah-Frimpong, G., \& Agyei-Sakyi, M. (2014). Assessing the Contributions of Small and Medium Sized Enterprises To Ghana's Economic Growth. International Journal of Economics, Commerce and Management, 2(11), 1-14.

43. Nwogu, S., Makinde, F., Okere, A., Utebor, S., Onuba, I., \& Nnodim, O. (2017, February 8). Has Nigeria Benefitted from Privatisation of the Power Sector. The Punch Nigeria Online. Retrieved from http://punchng.com/nigeria-benefitted-privatisation-power-sector/

44. Nwosa, P. I., \& Oseni, I. O. (2012). The impact of Banks Loan to SMEs on Manufacturing Output in Nigeria. Journal of Social and Development Sciences, 4(5), 212-217.

45. Nyanzu, F., \& Adarkwah, J. (2016). Effect of Power Supply on the performance of Small and Medium Size Enterprises: A comparative analysis between SMEs in Tema and the Northern part of Ghana Frederick. Munich Personal RePEc Archive. Retrieved from https://mpra.ub.uni-muenchen.de/74196/1/MPRA_paper_74196.pdf

46. Ogechukwu, A. D. (2011). The Role of Small Scale Industry in National Development in Nigeria. Universal Journal of Management and Social Sciences, 1(1), 23-41.

47. Ojo, M. (2006). Eliminating the Audit Expectations Gap : Myth or Reality? Munich Personal RePEc Archive, (232).

48. Okafor, G. I., Ugwuegbe, U., \& Ezeaku, C. (2016). IMPACT OF SMALL AND MEDIUM-SIZED ENTERPRISE ON THE GROWTH OF THE NIGERIAN ECONOMY- A Co-integration Approach. International Journal of Economics, Commerce and Management, IV(6), 678-692.

49. Okeke, A. U., Ezenwafor, J., \& Femiwole, R. (2013). Entrepreneurs' Reported Challenges and Opportunities of Global Financial Crisis on Small Business Operations in Anambra and Ekiti States, Nigeria.

50. Okoro, O. I., \& Chikuni, E. (2007). Power Sector reforms in Nigeria: Opportunities and Challenges. Journal of Energy in Southern Africa, VOl. 18(No. 3).

51. Okufolami, D. M. (2003). "Central Bank Of Nigeria Seminar On Small And Medium Industries Equity Investments SCHEME (SMIEIS). Lagos: Publication of CBN Training Centre, Lagos.

52. Olayemi, S. O. (2012). Electricity Crisis and Manufacturing Productivity in Nigeria. Developing Country Studies, 2(4), 16-21.

53. Oyedepo, S. O. (2012). Energy and sustainable development in Nigeria: the way forward, 2(15). https://doi.org/10.1186/2192-0567-2-15

54. Penrose, E. T. (1995). The Theory of the Growth of the Firm. Oxford University Press, USA.

55. Premium Times. (2017, January 22). Nigeria: Power Generation Drops to 2,662 Megawatts. Thisday Newspaper. Retrieved from http://allafrica.com/stories/201701220117.html

56. Price, C. W., Brigham, B., \& Fitzgerald, L. (2002). Service quality in regulated monopolies. (CCR Working Paper).

57. Rud, \& Pablo, J. (2012). "Electricity Provision and Industrial Development: Evidence from India." Journal of Development Economics, 97, 352-367.

58. Sambo, A. . (2005). Renewable Energy For Rural Development: The Nigerian Perspective. ISECO Science and Technology Vision, 1(12-22).

59. Scott, A., Darko, E., Lemma, A., \& Rud, J. (2014). How does electricity insecurity affect businesses in low and middle income countries?

60. Sheu, D. D., \& Lin, J. (2006). Equipment management strategy under machine capacity loss. International Journal of Production Economics, 103(1), 308-315.

61. Sivarethinamohan, R. (2010). Industrial relations and labour welfare: Text and cases. PHI Learning Pvt. Ltd.

62. Søilen, K., \& Onuorah, P. (2009). The role of Small and Medium Sized Enterprises for Economic Growth: A Case Study of Matori LGA in Lagos, Nigeria. Blekinge Institute of Technology, School of Management. Retrieved from http://www.diva-portal.org/smash/record.jsf?pid=diva2\%3A828348\&dswid=-3162

63. Steinbuks, J., \& Foster, V. (2010). When do firms generate? Evidence on in-house electricity supply in Africa. Energy Economics, 32(3), 505-514. https://doi.org/10.1016/j.eneco.2009.10.012 
64. Subramanian, R., Gupta, S., \& Talbot, B. (2009). Product Design and Supply Chain Coordination Under Extended Producer Responsibility. Production and Operations Management, 18(3), 259-277. https://doi.org/10.1111/j.1937-5956.2009.01018.x

65. The Bankers Committee, N. (2016, November 2). Diversifying Nigeria's economy. Business Day Online News. Retrieved from https:/www.businessdayonline.com/diversifying-nigerias-economy/

66. The Economist. (2016, March). Electricity in Nigeria: Powerless. The Economist Online. Retrieved from http://www.economist.com/news/middle-east-and-africa/21693971-nigeria-has-about-much-electricityedinburgh-problem-powerless

67. The Punch, N. (2016, January 25). Manufacturing's contribution to GDP hits N6.16bn. The Business News. Retrieved from http://businessnews.com.ng/2016/01/25/manufacturings-contribution-to-gdp-hits-n6-16bn/

68. Ukpong, I. I. (1973). The Economic Consequences of Electric Power Failures. The Nigerian Journal of Economic and Social Studies, 15(1), 53-74.

69. Vita, G. De, \& Kyaw, K. S. (2008). Determinants of FDI and Portfolio Flows to Developing Countries : A Panel Cointegration Analysis. Journal European Sciences Administrative, (13). Retrieved from https://www.researchgate.net/profile/Glauco_Vita/publication/228998454_Determinants_of_FDI_and_portfolio _flows_to_developing_countries_A_panel_cointegration_analysis/links/00b7d53089fb22c593000000.pdf

70. Wald, J. K. (1999). How firm characteristics affect capital structure: an international comparison. Journal of Finance Research, (22), 161-188.

71. Woo, R., Hu, H. D., Yang, K. R., \& Zhang, X. (2012). Political relations, tax advantages and companies' performances: examples from China. China Economic Review.

72. Yoo, S., \& Kim, J. (2015). The Dynamic Relationship between Growth and Profitability under Long-Term Recession: The Case of Korean Construction Companies. Sustainability, 7(12), 15982-15998.

73. Yusuf, T. O., \& Dansu, F. S. (2013). SMEs, Business Risks and Sustainability in Nigeria, 2(9), $76-94$. 